\title{
Studies on Different Types of Losses for Paddy Crop on Modified Multi-Crops Thresher
}

\author{
Nishanth M. Stanly ${ }^{1}$, Arun Kumar ${ }^{2}$, Ratnakiran D. Wankhade ${ }^{3 *}$ and Ekta Sharma ${ }^{4}$ \\ Department of Farm Machinery and Power Engineering, College of Technology, \\ G.B.P.U.A \& T., Pantnagar, Uttarakhand, India \\ *Corresponding author
}

\begin{tabular}{l} 
K e y w o r d s \\
Multicrop, \\
Performance, \\
Modification, \\
Losses \\
Article Info \\
$\begin{array}{l}\text { Accepted: } \\
\text { 25 February } 2020 \\
\text { Available Online: } \\
\text { 10 March } 2020\end{array}$ \\
\hline
\end{tabular}

The small axial flow multicrop thresher was modified and its performance was evaluated in respect of different threshing losses at different cylinder speeds and concave clearances. Commonly available wheat/paddy threshers are not suitable for handling wide range of crops grown by farmers of hill region. Thresher was designed and fabricated in Department of Farm Machinery and Power Engineering, Pantnagar. The thresher consisted of threshing cylinder, concave assembly, cleaning unit, belt-pulley arrangement, and aspirator assembly mounted on a frame. The thresher was evaluated for its performance in the Department of Farm Machinery and Power Engineering during. The crops were taken from Crop Research Center, Pantnagar. The major emphasis of the study was to check the performance of the thresher after modification.

\section{Introduction}

In present era of modernization, farming practices are still lacking innovative approaches for the various crop handling operation. Application of energy may result in high yield and precision in the farming. The use of farm implements and machineries provide the timeliness in uncertain farming of India. Full-scale mechanization is not needed as in other developed countries of the world. However, the large holdings can safely be mechanized. The farming scenario of Indian agriculture is changing day by day. Initially (just after independence) Indian agriculture was attributed as bullock based farming practices.

Government of India has initiated various schemes to rebuild the farming system to adopt the advance science and technological practices in farming. The Indian scenario relating to use of farm machineries in various regions differ significantly from each other. Keeping the above point in view a multicrop thresher was modified and tested for its 
performance on basis of various threshing losses in the Department of Farm machinery and Power engineering, G.B. Pant University, Pantnagar.

\section{Materials and Methods}

The performance evaluation of thresher was conducted according to experimental technique BIS IS: 6284-1985 and IS: 63201985. This experiment was carried out at Department of Farm Machinery and Power Engineering Department. The view of modified multicrop Thresher which was used for threshing is shown in Plate 1.

\section{Losses}

Losses are of three types in thresher and these losses were measured in percentage and determined by using the following standard equations.

\section{Sieve loss $\left(\mathbf{S}_{\mathbf{L}}\right)$}

The quantity of clean grain collected from sieve over flow and under flow per unit time divided by the total grain input per unit time.

$\mathrm{S}_{\mathrm{L}}(\%)=$



\section{Cylinder loss $\left(\mathrm{C}_{\mathrm{L}}\right)$}

The quantity of threshed and unthreshed grain collected from cylinder outlet per unit time divided by the total grain input per unit time.

$\mathbf{C}_{\mathbf{L}}(\%)=$

Free clear graincollected from the cylinder outlet per unittime $\times 100$

Total grain inputper uint time

\section{Blower loss $\left(\mathrm{B}_{\mathrm{L}}\right)$}

The quantity of clean grain collected from the blower outlet per unit time divided by the total grain input per unit time.

$\mathbf{B}_{\mathbf{L}}(\%)=$

$\frac{\text { Free clear grain collected from the blower outlet per unit time }}{\text { Total grain input per nint time }} \times 100$

\section{Results and Discussion}

Effect of cylinder speed and cylinderconcave clearance on different losses

Effect of cylinder speed and cylinder-concave clearance on different losses was observed. The different losses namely sieve loss, cylinder loss and blower loss at different cylinder speed and different cylinder-concave clearance is given in Table 2 and their relationship is shown in Fig. 1, 2 and 3.

\section{Cylinder loss}

Cylinder speed is an important operating parameter with regards to cylinder loss. The graph (Fig. 1) indicates that with the increase in cylinder speed the cylinder loss reduced. It was also observed that when cylinder-concave clearance decreased, more cylinder loss occurred because of the reason that more unthreshed grain was received at the cylinder outlet.

At less concave clearance the grain and the straw not getting the sufficient gap to get pass into the lower concave. So when a large opening is getting at the cylinder outlet straw comes out with grain. This causes more grain loss at lower concave clearance. At every concave clearances similar phenomena observed that the cylinder loss decreased with increase in cylinder speed at each concave clearance. The cylinder loss ranged from 0.85 to $2.56 \%$. The minimum cylinder loss of 0.85 $\%$ was found at cylinder speed of $570 \mathrm{rpm}$ $(11.04 \mathrm{~m} / \mathrm{s}$ ) with $30 \mathrm{~mm}$ cylinder concave clearance also the maximum loss of $2.56 \%$ 
was observed at cylinder speed of $570 \mathrm{rpm}$ (11.04 $\mathrm{m} / \mathrm{s})$ and at cylinder-concave clearance $15 \mathrm{~mm}$. Statically there is significant effect $(\mathrm{P}<0.05)$ of cylinder speed and cylinder-concave clearance $(\mathrm{P}<0.01)$ on cylinder loss. The interaction of the parameters is found non-significant.

\section{Blower loss}

Fig. 2 shows the effect of cylinder speed and cylinder-concave clearance on blower loss. From graph it was observed that increase in the cylinder speed causes blower loss to decrease except in the case of $10,30 \mathrm{~mm}$ concave clearance. It was due to the reason that at lower cylinder-concave clearance more breakage occurs and it was sucked by suction tunnel of aspirator assembly. In two cases (30, $20 \mathrm{~mm}$ concave clearance) it was also observed that at higher speed the blower loss increases due to the fact that the impact force imparted to the crop is maximum and causes more breakage which is sucked up by the aspirator leads to more aspirator loss.

The minimum loss of $1.95 \%$ was found at cylinder speed of $370 \mathrm{rpm}(7.16 \mathrm{~m} / \mathrm{s})$ with 30 $\mathrm{mm}$ cylinder-concave clearance whereas; the maximum loss of $3.42 \%$ was noted at cylinder speed of $370 \mathrm{rpm}(7.16 \mathrm{~m} / \mathrm{s})$ with 15 $\mathrm{mm}$ concave clearance. When the concave clearance increases there was a considerable change in the blower loss. The maximum blower loss was observed at minimum concave clearance. Statically the effect of concave clearance is significant $(\mathrm{P}<0.05)$.

\section{Sieve loss}

It is evident from Fig. 3 that in general, the sieve loss increased with increase in cylinder speed at all concave clearances, due the reason that when cylinder speed increases the sieve oscillation increases accordingly which leads to more loss of grain through the sieve. The Figure 3 also indicates that the increase in concave clearance decreases the sieve loss due to the fact that at lower concave more straw is forced to pass through the lower concave and it would be accumulated over the sieve which in turn creates problem for the aspirator to suck all the straw. Due to this accumulation the grain over the straw will spill to the ground over the sieve which causes the sieve loss. The data is given in the Table 2.

Table.1 Parameter Selected

\begin{tabular}{|c|c|c|c|}
\hline S.No. & Independent & Parameter & Dependent \\
\hline & $\begin{array}{c}\text { Concave } \\
\text { clearance }(\mathbf{m m})\end{array}$ & $\begin{array}{c}\text { Cylinder speed } \\
(\text { rpm })\end{array}$ & Losses \\
\hline 1. & C1-15 & N1-370 & a) Sieve loss (SL) \\
\hline 2. & $\mathrm{C} 2-20$ & N2-470 & b) Cylinder loss (CL) \\
\hline 3. & $\mathrm{C} 3-25$ & N3-570 & c) Blower loss (BL) \\
\hline 4. & C4-30 & & \\
\hline
\end{tabular}


Table.2 Threshing losses at different cylinder speeds and concave clearances for paddy

\begin{tabular}{|c|c|c|c|c|c|c|}
\hline $\begin{array}{c}\text { SI } \\
\text { no }\end{array}$ & $\begin{array}{c}\text { Treatment } \\
\text { combination }\end{array}$ & $\begin{array}{c}\text { Concave } \\
\text { clearance } \\
(\mathbf{m m})\end{array}$ & $\begin{array}{c}\text { Cylinder } \\
\text { speed } \\
(\mathbf{r p m})\end{array}$ & \multicolumn{3}{|c|}{ Thresher losses } \\
\hline $\mathbf{1}$ & $\begin{array}{c}\text { Cylinder } \\
\text { loss (\%) }\end{array}$ & $\begin{array}{c}\text { Blower } \\
\text { loss (\%) }\end{array}$ & $\begin{array}{c}\text { Sieve } \\
\text { Loss (\%) }\end{array}$ \\
\hline $\mathbf{2}$ & $\mathrm{C}_{1} \mathrm{~N}_{1}$ & 15 & 370 & 2.31 & 3.42 & 2.20 \\
\hline $\mathbf{3}$ & $\mathrm{C}_{1} \mathrm{~N}_{2}$ & 15 & 470 & 2.42 & 3.16 & 2.21 \\
\hline $\mathbf{4}$ & $\mathrm{C}_{1} \mathrm{~N}_{3}$ & 15 & 570 & 2.56 & 2.96 & 2.34 \\
\hline $\mathbf{5}$ & $\mathrm{C}_{2} \mathrm{~N}_{1}$ & 20 & 370 & 1.95 & 2.89 & 1.96 \\
\hline $\mathbf{6}$ & $\mathrm{C}_{2} \mathrm{~N}_{2}$ & 20 & 470 & 1.71 & 2.97 & 1.97 \\
\hline $\mathbf{7}$ & $\mathrm{C}_{2} \mathrm{~N}_{3}$ & 20 & 570 & 1.42 & 3.12 & 2.15 \\
\hline $\mathbf{8}$ & $\mathrm{C}_{3} \mathrm{~N}_{1}$ & 25 & 370 & 1.12 & 2.98 & 1.13 \\
\hline $\mathbf{9}$ & $\mathrm{C}_{3} \mathrm{~N}_{2}$ & 25 & 470 & 0.98 & 2.45 & 1.12 \\
\hline $\mathbf{1 0}$ & $\mathrm{C}_{3} \mathrm{~N}_{3}$ & 25 & 570 & 0.97 & 2.53 & 1.25 \\
\hline $\mathbf{1 1}$ & $\mathrm{C}_{4} \mathrm{~N}_{1}$ & 30 & 370 & 0.96 & 1.95 & 1.28 \\
\hline $\mathbf{1 2}$ & $\mathrm{C}_{4} \mathrm{~N}_{2}$ & 30 & 470 & 0.96 & 1.99 & 1.45 \\
\hline $\mathrm{C}_{4} \mathrm{~N}_{3}$ & 30 & 570 & 0.85 & 2.25 & 1.98 \\
\hline
\end{tabular}



Fig.1 Cylinder loss vs Cylinder Speed for Paddy 
Int.J.Curr.Microbiol.App.Sci (2020) 9(3): 3195-3200

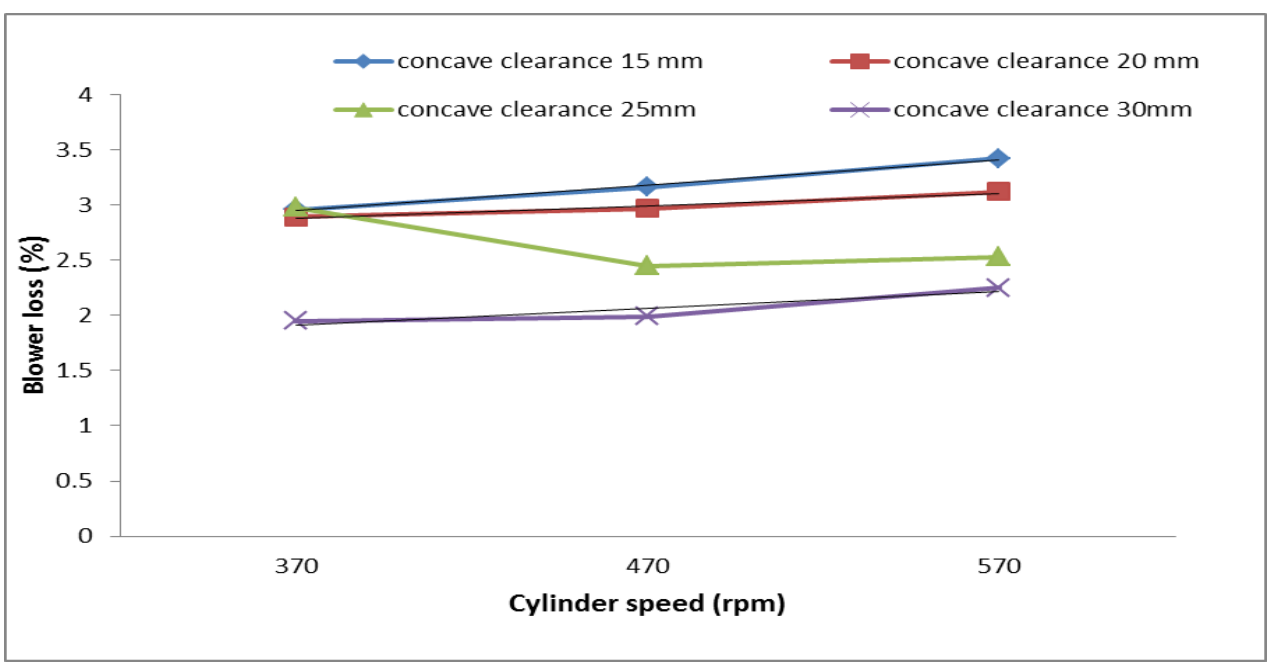

Fig.2 Blower Loss vs Cylinder Speed for Paddy

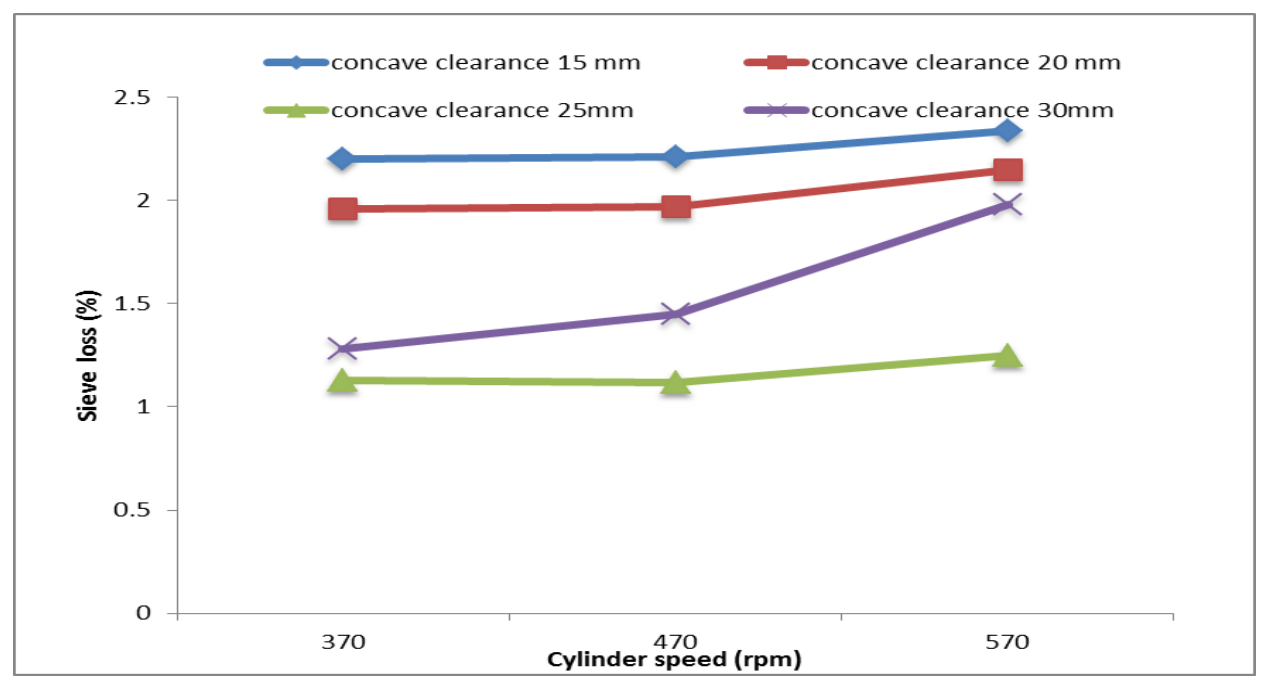

Fig.3 Sieve loss vs Cylinder Speed

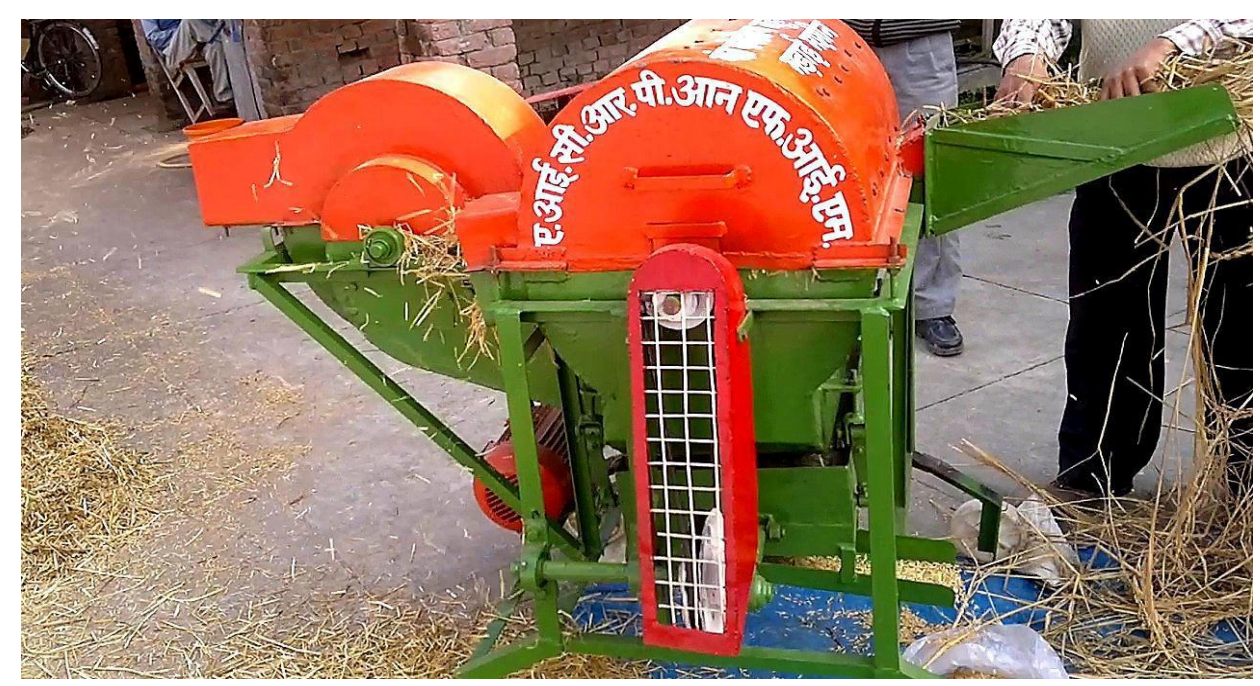

Plate.1 Modified multicrop Thresher during paddy Threshing 
The minimum loss of $1.12 \%$ was found at cylinder speed of $470 \mathrm{rpm}(9.09 \mathrm{~m} / \mathrm{s})$ with 25 mm cylinder-concave clearance whereas; the maximum loss of $2.34 \%$ was noted at cylinder speed of $570 \mathrm{rpm}(11.04 \mathrm{~m} / \mathrm{s})$ with $15 \mathrm{~mm}$ concave clearance. Statically concave clearance and cylinder speed have significant $(\mathrm{P}<0.05)$ effect.

It is clear from the Table 2 that total loss viz. sieve loss, cylinder loss and blower was found in the range of 4.19 to $7.86 \%$. Maximum grain loss of $7.86 \%$ was found at $570 \mathrm{rpm}$ cylinder speed with $15 \mathrm{~mm}$ cylinder-concave clearance and minimum loss was $4.19 \%$ at $370 \mathrm{rpm}$ with 30 cylinder-concave clearances. The total grain loss is less than $5 \%$ for all combinations of $25 \mathrm{~mm}$ concave clearance, which is also according to BIS standard in which recommendation is the total grain loss should be less than $5 \%$.

It is concluded from the results that the modified thresher is successfuel for the paddy threshing on the selected parameters.

\section{References}

Indian Standard Codes. 1985. Test code for power thresher for cereals. IS: 6284 II, Indian Standard Institute, New Delhi, India.

Indian Standard Codes. 1985. Test code for power thresher for cereals. IS: 6320 II, Indian Standard Institute, New Delhi, India.

\section{How to cite this article:}

Nishanth M. Stanly, Arun Kumar, Ratnakiran D. Wankhade and Ekta Sharma. 2020. Studies on Different Types of Losses for Paddy Crop on Modified Multi-Crops Thresher. Int.J.Curr.Microbiol.App.Sci. 9(03): 3195-3200. doi: https://doi.org/10.20546/ijcmas.2020.903.366 